DANMARKS PÆDAGOGISKE UNIVERSITETSSKOLE, AARHUS UNIVERSITET

- FORSKNINGSENHEDEN BARNDOM, LÆRING OG DIDAKTIK [WWW.DPU.DK/BLD]

\title{
EARLY LITERACY: TOWARDS A UNIFIED APPROACH FOR CHILDCARE AND SCHOOL
}

\begin{abstract}
This paper discusses findings from the Danish contribution to the EASE project, a European research project running from 2008-2010 on early literacy in relation to the transition from childcare to school. It explores a holistic, inclusive approach to early literacy that resists a narrow, accountability-oriented Danish policy (mirroring international trends). The paper draws on Broström's (2006a, 2006b, 2008, 2009) reconceptualization of early childhood education and care (ECEC), which conceives of care, upbringing and teaching as a unified whole, challenging both childcare services and schools. The paper also draws on Gee's $(2001,2003,2004,2008)$ sociocultural approach to literacy, and Honneth's $(2003,2006)$ concept of recognition. Emphasizing participation and recognition as key elements, it claims that stakeholders in early literacy must pay attention to how diverse early literacy opportunities empower children, especially when these opportunities are employed in a projectbased learning environment in which each child is able contribute to the shared literacy events.
\end{abstract}

\section{Keywords}

Holistic, early literacy, teaching, childcare, school, unified approach

Denmark was one of eight European countries that participated in the EASE project (EASE, 2010). EASE is an abbreviation of 'early years transition programme', which was a research project running from 2008-2010 that aimed at strong and equal partnerships between childcare services and schools in order to improve educational continuity and facilitate the children's (ages 5-7) transition from childcare to school. One key aspect was to develop a unified approach to early literacy, meaning that childcare workers and schoolteachers were trained together with the intent of facilitating a common understanding of early literacy that could be adopted on both the childcare and the school side of the transition.

To this end, the researchers collaborated on an early literacy adaptation of the Learning Story approach developed by Margaret Carr (2005) in New Zealand. Learning stories document children's learning processes in the form of small narratives of- 
DANMARKS PÆDAGOGISKE UNIVERSITETSSKOLE, AARHUS UNIVERSITET

- FORSKNINGSENHEDEN BARNDOM, LÆRING OG DIDAKTIK [WWW.DPU.DK/BLD]

ten accompanied by photos, drawings or other ways of illustrating the events documented. These stories are written on a pre-designed sheet, which also prompts the childcare workers and schoolteachers to reflect on 'what happened' and 'what could be next' in relation to the learning processes evident in the narrative (Carr, 2005; Mellgren, et al., 2010).

Carr's original approach has a somewhat general focus on children's learning and personal development. The EASE project was - in contrast - based on a specific interest in early literacy. The participating researchers agreed on a list of early literacy indicators that were intended to help the childcare workers and schoolteachers discover the early literacy qualities in the activities of the children. In this way the indicators had a 'what to look for' function. As we wanted to emphasize a broad perspective on early literacy, the indicators pointed to literacy aspects of children's play, drawing and storytelling (Broström, 2003; Davidson, 1996; Kress, 1997; Roskos \& Christie, 2007), and not just conventional reading and writing activities. Together with a slightly modified template for the narrative, photos, reflections etc., these indicators make up what has come to be called the Early Literacy Story approach of the EASE project (Jensen, Hansen, \& Broström, 2010; Mellgren, et al., 2010).

In Denmark, childcare workers and schoolteachers from two municipalities agreed to participate in the project. They were brought together for in-service training regarding a socio-cultural perspective on early literacy in general, and on how to document early literacy using the Early Literacy Stories in particular. Then they went back to their respective practices and tried to use the Early Literacy Stories to document early literacy. The Danish researchers visited the participants to supervise them and to discuss their experiences with the documentation tool.

During the project we learned that by employing a list of indicators, we risk 'narrowing' the pedagogic practice. From a critical position, indicators are viewed as promoting an undesirable so-called tick-off approach to assessment (Dahlberg, Moss, \& Pence, 2007) in which focus is on the child's weaknesses or deficits as deducted from a standardized curriculum (shown by the indicators). The earliest versions of the early literacy learning story template actually had the indicators as a tick-off list next to the actual story, but this design was eventually abandoned, as it did not connect with the underlying socio-cultural basis of the EASE approach. We even tried to do without the indicators, but some of the childcare workers and schoolteachers objected. They found the indicators highly useful in the task of spotting diverse strands of early literacy in the children's activities.

As we experienced the tensions in working with a holistic, socio-cultural approach supported by early literacy indicators, we began to discuss how theory guiding early literacy teaching practice might include indicators and teaching methods as well as an emphasis on the need to contest instrumentality and standardization, thus providing the tools for questioning the relations between rationalistic/economic discourses and the image of early literacy learning as a process of individual acquisition

Anders Skriver Jensen Ph.d.-stipendiat, cand.pæd. asje@dpu.dk
Institut for Didaktik

Danmarks Pædagogiske Universitetsskole

Aarhus Universitet 
DANMARKS PÆDAGOGISKE UNIVERSITETSSKOLE, AARHUS UNIVERSITET

- FORSKNINGSENHEDEN BARNDOM, LÆRING OG DIDAKTIK [WWW.DPU.DK/BLD]

of cognitive skills. Along with the childcare workers and teachers we wanted to struggle with inclusive teaching practices beyond the common-sense interest in leaving no child behind in a race to acquire skills.

I do not argue for 'freeing' teaching from curricula and indicators. In fact I believe that curricula and indicators are inevitable dimensions of institutionalized early literacy teaching, as pedagogy is always inscribed in values and relations of power. Thus claiming a 'free' practice is more like claiming a practice of tacit indicators and hidden curricula. Instead, the real challenge seems to be how to position early literacy teaching in relation to the domains of policy (school effectiveness), curricula and indicators, and the children's own perspectives.

The rest of this paper deals with this complex challenge. I will use an excerpt from an influential, freshly published Danish policy document to suggest that wordings on this level implicitly produce a narrow image of early literacy as the acquisition of fundamental skills and closely tied to schooling outcomes. I will then analyze an Early Literacy Story with theory drawn from sociolinguistics, ECEC curriculum studies and critical theory to go beyond the taken-for-granted images of the policy level in an attempt to sketch some dimensions in a holistic and inclusive approach to early literacy teaching. In line with the aims of the original EASE project, this approach tries to appeal to both childcare workers and schoolteachers, thus contributing to the ongoing attempts to promote continuity throughout the ECEC by making unified theoretical and practical concepts available to the practitioners (Broström, 2006a).

\section{Policy - And Resistance!}

In an international ranking of children's reading skills conducted in 1994, Denmark was ranked relatively low (Mejding, 1994). In the Danish public and professional debates that followed, this was perceived as very embarrassing, and influenced the policy level in a somewhat shock-like way (Laursen \& Hildebrandt, 2009). Ten years into the new millennium the shock has worn off, but a discourse on how to respond to the growing influence of the cross-national benchmarking projects has established itself in a dominating position. Mirroring contemporary trends in other OECD countries, influential strands of Danish educational policy promote an 'accountability-approach' (Rasmussen, 2007), where schools and childcare services are expected to explain the so-called 'schooling outcomes' in terms of effectiveness and quality. This discourse of quality emphasizes a) the standardization of curriculum and b) the competition among schools on the quasi-market of education (Dahlberg, et al., 2007). It thus promotes the image of learning as the acquisition of discrete skills and the notion that this acquisition process should be the object of close scrutiny In order to assess the effectiveness of the teaching and the extent to which the learning is in sync with what is expected for a child of a given age. Thus effective 
DANMARKS PÆDAGOGISKE UNIVERSITETSSKOLE, AARHUS UNIVERSITET

- FORSKNINGSENHEDEN BARNDOM, LÆRING OG DIDAKTIK [WWW.DPU.DK/BLD]

teaching is about employing 'developmentally appropriate practices'; practices that yield good results in the realm of international comparative education.

To link these more general considerations on teaching and accountability directly to early literacy, I will now examine an excerpt from a contemporary Danish policy document concerned with early literacy and school effectiveness.

The Danish Government recently (2010) published a general political strategy aimed at overcoming the financial crisis and at developing Denmark as a nation with special regard to the themes of knowledge, economic growth, prosperity and welfare.

This political strategy is based on 10 'aims for Denmark' to be reached by the year 2020. One of these aims concerns the excellence of Danish pupils, stating that they should be among the best in the world. More precisely, Denmark should be in the top five in the PISA benchmarks, which compare schooling outcomes on an international level (OECD, n.d.). The Danish Government's strategy relies on a sports analogy to explain what is expected of the pupils: just as the sportsman/woman practices hard to excel, so must the pupils practice to reach top rankings in PISA.

In formulating these aims, the Danish Government has implicitly constructed a certain position on early literacy. Consider the following excerpt from the political strategy, which concerns early literacy teaching:

The Government wants to prioritize reading in the lower grades. Other fundamental skills must likewise be in place at an early stage: Orality, literacy, and basic competencies in mathematics, science and foreign languages. This will mean a strong focus on leaving no child behind, including those children that have difficulties in learning to read ... we want to change the way we run public schools. They must be allowed more freedom to maneuver; on the other hand, we will hold them accountable for the results they achieve. (The Danish Government 2010, p. 16, translated by the author).

Several aspects of this excerpt are of particular importance. First is the view of reading. While it states that schools must prioritize reading in the lower grades, the Danish government suggests that not only is reading a discrete skill to be mastered (put 'in place'), but it is one of several in a category of 'fundamental skills' and 'basic competencies' (Hoover \& Gough, 1990; Westwood, 2009). Second, the Danish government does not only reveal how it defines orality and literacy, but also, by linking the teaching of these basics to the concern for 'leaving no child behind', moves down a path where the pupils fall into two categories: those who have acquired the basic skills and those we might call special needs children who have 'difficulties in learning to read' (i.e. in acquiring the basic skills). Finally, the images of the class as a moving entity you have to keep up with frames inclusion as a technical matter of the teacher ensuring that everybody in the class meets the requirements of a norm (a reading skill level deemed sufficient for a given age, that is, developmentally appropriate) without relegating pupils to potentially stigmatizing compensatory education (Bern- 
DANMARKS PÆDAGOGISKE UNIVERSITETSSKOLE, AARHUS UNIVERSITET

- FORSKNINGSENHEDEN BARNDOM, LÆRING OG DIDAKTIK [WWW.DPU.DK/BLD]

stein, 1972; Madsen, 2005, 2009; Søndergaard, et al., 2005). This surely satisfies the aim of keeping schools focused on results, but what about the ethical and social consequences of conceiving of teaching as the transmission of skills and of introducing standards that schools, teachers and pupils compete to excel at (Amrein \& Berliner, 2003; Hatch, 2002; Nichols \& Berliner, 2007; Noddings, 2007; Nordenbo, 2009)?

This does not mean that a cognitive approach to early literacy is inferior, nor does the socio-cultural approach that I support mean lowering the bar with regards to 'hardcore' cognitive/academic expectations. The aim of the analysis is to instill a general awareness of how contemporary policy (produced from within the project of neo-liberalism in a globalized economy) repositions matters of curriculum theory to fit within a technical domain (Dahlberg, et al., 2007; Rhedding-Jones, 2007). This policy might improve the educational system's performance in international benchmarks such as comparative reading and writing tests, but it is also part of a regime that potentially 'schoolifies' the childcare services by letting education (as in formal skills-training) outmaneuver care:

There is an effort for shaping a unity of care and education, and like this a movement towards the educare concept. However, there is a fear for more education than care, and to realize the idea of early school oriented learning, what we in the Nordic countries name 'schoolification'... The educational changes [are] based on an economic interest, and the attached political statements have big impact on national initiatives, where we see distinct formulations of goals and objectives close connected to a number of simplified methods connected with pre-described tests ... An ongoing boosting of such tendencies will colonize the soul of the early childhood education and care tradition, and for that reason we have to re-construct a critical early childhood education (Broström, 2008: 10).

Following Foucault (2000), we have to recognize the importance of the wordings of policy texts, because they produce systems of truths and discourses, i.e. our understanding of what is possible and desirable within the domain of early literacy and early childhood education as a whole. As Lenz-Taguchi (2010) points out, it seems as if the more we know about the complexities involved in young children's learning and meaning-making, the more we shape policy around narrow, complexity reducing curricula and teaching strategies. In Denmark, there is a tendency to emphasize school-effectiveness and best practices across the field of contemporary early childhood education and care, even though the democratic dimensions are still relatively strong (Jensen, Broström, \& Hansen, 2010). If you do not like a particular discourse, you must construct an alternative to that discourse (Rhedding-Jones, 2007). It is not just a game of words: the ways we think and act are formed by the discourses that surround and govern us.

To sum up, it is possible to identify links between policy on school effectiveness and an emphasis on discrete, cognitive skills within the domain of early literacy. Early literacy is certainly about cognitive skills, but we must resist an overemphasis on 
DANMARKS PÆDAGOGISKE UNIVERSITETSSKOLE, AARHUS UNIVERSITET

- FORSKNINGSENHEDEN BARNDOM, LÆRING OG DIDAKTIK [WWW.DPU.DK/BLD]

breaking up complex identity issues and communicative competencies into discrete, testable skills. What is needed is a holistic approach to early literacy teaching that reaches beyond (but does not neglect) the cognitive aspects of decoding, lexical comprehension, indicators and standards. I will try to sketch such an approach in the following section, where I examine an early literacy story.

\section{Theoretical Resources}

The following theoretical resources have been selected using one main criteria which is the ability to conceive of early literacy teaching (and teaching more generally) in ways that emphasize participation, illuminating how early literacy is inscribed in complex socio-cultural processes beyond the cognitive dimension. To some extent the theoretical framework is composed as an act of resistance, empowering researchers, childcare workers and teachers to create diverse links between children, culture and the early literacy curriculum by foregrounding an awareness of issues not being articulated in contemporary early literacy policy.

James Paul Gee's socio-cultural approach to early literacy emphasizes how language-in-use (which he terms discourse ('little d')) is entangled in social practices, values and communities (termed Discourse, with a capital ' $\mathrm{D}$ '). A literacy event is thus always tied to one or more Discourses, and individuals must 'pull of' (enact) a Discourse (a culturally specific kind of identity) in order to be 'in sync' with (act in accordance with) a given community at a given place and time (Gee, 2001, 2008). The home, the childcare and the kindergarten (kindergarten, also called grade zero, is the first year of the Danish public school) are examples of three distinct communities (or social semiotic domains), each requiring a different set of Discourses (identities) for the children to pull of, if they want to be in sync with the early literacy practices. With the concept of Discourse we can examine how being a literate person is about being able to cognitively act on a text (decode, comprehend, etc.) as well as being able to socially and morally act on this text in accordance with the practices, values, norms and resources tied to a given community (i.e. the classroom). You are never 'just' a reader or a writer, you are with varying degrees of success synching with communities by enacting particular sorts of Discourses. This is in line with Kress (1997: 47), who points to the identity-related question of what kind of reader and writer we want, when we discuss theories and practices in relation to early literacy.

To answer Kress' question, and to work directly with theory that ties early literacy to a critical stance towards the above-mentioned schoolification (which might be understood as the transformation of the childcare Discourse to the (rigid) school Discourse, using Gee's terms), I draw on Stig Broström's reconceptualization of early childhood education and care. It departs from the care concept, and unifies the concepts of care, upbringing and teaching into a critical and holistic approach, intended to be a used in the growing cooperation of workers in childcare centers and so-called 
DANMARKS PÆDAGOGISKE UNIVERSITETSSKOLE, AARHUS UNIVERSITET

- FORSKNINGSENHEDEN BARNDOM, LÆRING OG DIDAKTIK [WWW.DPU.DK/BLD]

leisure time centers (after school programs), and the teachers in schools (including kindergartens) (Broström, 2006a). Inscribed in the continental Bildung (liberal education) tradition, concerned with deliberative education for democracy (Beiser, 1998; Broström, 2009; Klafki, 2001), Broström's reconceptualization challenges 1) childcare workers to work with learning and education, and 2) schoolteachers to take a caring, child-centered stance on curricula.

It is emphasized that childcare workers and teachers should collaborate on more than just the teaching of skills and social competencies in an attempt to facilitate a good transition from childcare to school. The work of childcare workers and schoolteachers throughout the ECEC should be carried out under the overarching theme of education for democracy:

On the one hand preschool teachers [childcare workers] have to take the specific school curriculum into consideration and make up a preschool [childcare service] education which prepare children to school and help them to school success. Anything else would be irresponsible. However at the same time preschool teachers must realize, this is not enough. The society also needs active critical citizens, who want to use their knowledge, to show courage and autonomy, take responsibility and seek influence... This calls for a lively early childhood education and care where the preschool teachers create an environment in which children can achieve democratic experiences. It is my hope - that preschool and school in the future will be able to collaborate in order to handle this double and cooperative purpose (Broström, 2008: 18).

With regards to early literacy teaching this might mean - to answer Kress' question - that childcare workers and schoolteachers should collaborate on the formation of democratic readers and writers.

Axel Honneth focuses on what he calls the fight for recognition. This fight, ontological in character, is about how every subject creates itself on the basis of experiences of recognition, non-recognition and mis-recognition. These experiences lead to the formation of identity and develop important aspects of the self, i.e. self-worth, selfconfidence and self-respect (Honneth, 2003, 2006).

\section{Holistic Early Literacy Teaching: Thomas is a Reader!}

The following early literacy story was constructed during the EASE project, making it one of several collected over a semester of observations in childcare centers and kindergartens. The story is titled 'The Story About a Thief', and was collected in an urban kindergarten. It is about a boy who attends this kindergarten; we can call him Thomas. Thomas is six years old, and he experiments with literacy in ways that might inspire teaching practice not just in this particular kindergarten, but also in childcare and in the first years of school in general. This is not about Thomas being especially gifted; actually the following literacy event is pretty ordinary on the level 
DANMARKS PÆDAGOGISKE UNIVERSITETSSKOLE, AARHUS UNIVERSITET

- FORSKNINGSENHEDEN BARNDOM, LÆRING OG DIDAKTIK [WWW.DPU.DK/BLD]

of observable behavior. The inspiring potential unfolds as this event is approached from socio-cultural and critical positions within the realms of early literacy and early childhood education in general. In this way, the following event functions as a touchstone for an attempt to move from an analysis of Thomas' ability (or lack hereof) to decode letters and comprehend words on a simple, lexical level, to the sketching of two dimensions of a holistic, inclusive early literacy teaching practice in general.

Let us turn to Thomas:

It is lunchtime, and the children are eating at the table. Thomas has already finished his meal, and he wants to read a story aloud to his classmates. Thomas picks up a book from the 'book basket'. The book contains pictures and simple text, and it's a story he knows already. It's easy to see the excitement in Thomas' face: He is looking forward to sharing the action-packed tale of The Thief!

Thomas starts to read aloud, but suddenly he becomes aware of the audience (his classmates), who have all turned towards him on their chairs while quietly munching on their lunches. This sudden awareness of the audience clearly makes Thomas nervous, and he's having trouble focusing on decoding the text. But he won't give up. Thomas 'reads' the rest of the story using his prior knowledge of the story, his imagination and the pictures on the pages (which he from time to time pauses to show underway).

In the end, it turns out to be a really exciting story. Thomas, on the spot, narrates about the 'truck', the 'loot', the 'house in need of fixing' and other elements of the story in a rather new way. His classmates have laughed and nodded at key points during the story, and they applaud at the end.

The first point to note is the end of the second paragraph, where Thomas manages to continue reading even though he is 'having trouble focusing on decoding the text'. What happens is that Thomas expands the scope of the cognitive and cultural resources he is drawing on in the attempt to narrate the story. He is bringing in more cultural raw material to make meaning from/with, supplementing the decoding strategies with narrative abilities (Fox, 2003). In shifting between decoding and simple, lexical comprehension, prior knowledge, imagination, and pictures, Thomas is actually reaching a level of deeper comprehension (Gee, 2004), where he is comfortable rearranging (thus acting on) the otherwise pre-set elements. By changing his reading strategy, Thomas manages to stay in control of the literacy event. In this way Thomas actually succeeds as a reader - only partially in cognitive, technical terms but to the fullest in terms of identity. This leads to the next point:

Second, it is important how the classroom community of peers responded to Thomas' performance as a reader. Thomas' peers were interested in the story and they 'turned towards him on their chairs while quietly munching on their lunches', and they 'have laughed and nodded at key points during the story, and they applaud 
DANMARKS PÆDAGOGISKE UNIVERSITETSSKOLE, AARHUS UNIVERSITET

- FORSKNINGSENHEDEN BARNDOM, LÆRING OG DIDAKTIK [WWW.DPU.DK/BLD]

at the end'. It is clear that Thomas has made a valuable contribution to the community, and his peers acknowledge it. In fact Thomas' classmates learned to see him as one of those (identity) 'who read aloud from those books in the book basket', in the special school kind of way (standing up while reading, pausing underway to show pictures to classmates etc.) (Gee, 2008). This distinction between success in terms of skills and in terms of identity allows us as researchers and teachers to relate to Thomas in advance of his actual cognitive development, and to support a learning environment of experimentation and play ('playing a reader'), which has intrinsic value, but which also supports cognitive development (Holzman, 1997; Vygotsky, 1978), and early literacy learning in particular (Gee, 2001). Being recognized as a reader by his peers directly influences how Thomas sees and values himself (Honneth, 2003, 2006). With regard to inclusion, it is noteworthy that Thomas' success as a reader is facilitated by a collective activity. Not the teacher bringing reading material finely adjusted to fit Thomas' individual level of reading skills (developmentally appropriate learning opportunities (McCollin \& O'Shea, 2005)), but the teacher having established a tradition in the class, where the children in turn can play-read aloud from the books in the book basket.

To sum up, I have made two points in the brief analysis of Thomas' literacy event. The first point concerns the importance of providing Thomas with the opportunities to narrate, experiment and reach a level of deep comprehension when working with a text. These rich opportunities are not provided as a reading strategy (as in the 'Searchlights Model' discussed by Rose (2006)), and they are not provided as an addon or a set of more advanced activities that can be carried out after the decoding and lexical comprehension is complete. They are provided as a means to empower Thomas to take control of the literacy event and put himself in the text. The second point concerns how Thomas' performance as a reader takes the form of a valuable contribution to the community of peers, which is paramount in terms of recognition and identity.

I have made these points drawing on socio-cultural theory on literacy (Fox, 2003; Gee, 2008) as well as critical theory of recognition (Honneth, 2003, 2006). Apart from the obvious different perspectives that could have been generated by a cognitive approach (Gough \& Tunmer, 1986; Hoover \& Gough, 1990) - although the data presented are not fit for a detailed analysis of Thomas' decoding and comprehension skills - I think a perspective on power and subjectification might point to a relevant critique (Dahlberg, et al., 2007; Fendler, 2001). How does the transgression of the skills/identity divide function as a technology of regulation, providing a powerful tool for governing the whole child? How do children learn to create/govern themselves in relation to the teacher- and school based norms undergirding a sociocultural, holistic interpretation of their experiments with literacy? And how is this teaching, which supports and expects the children to bring most of their cultural resources into the teaching process, linked to the education of a flexible, creative work-

Anders Skriver Jensen Ph.d.-stipendiat, cand.pæd. asje@dpu.dk
Institut for Didaktik

Danmarks Pædagogiske Universitetsskole Aarhus Universitet 
DANMARKS PÆDAGOGISKE UNIVERSITETSSKOLE, AARHUS UNIVERSITET

- FORSKNINGSENHEDEN BARNDOM, LÆRING OG DIDAKTIK [WWW.DPU.DK/BLD]

force that fits into the Western world labor market of the globalized economy (Giroux, 2001; Giroux \& Giroux, 2006)? These issues will not be examined within the scope of this paper, but they remain sources of relevant critique.

In the following sections I will in turn explore the two analytical points in more depth, trying to sketch some implications for a holistic, inclusive early literacy theory and practice. The practical examples accompanying each point are inspired by research data and field experience.

\section{Rich Early Literacy Opportunities Empower Early Readers}

Despite qualified attempts to make concepts such as 'evidence' or 'scientific progress' account for what counts as early literacy (Snow, 2008), we cannot draw from a neutral realm of science or other transcendent places the answers to what cultural resources and practices are relevant in early literacy teaching. This is because the teaching (the school) in itself is a community linked to a certain Discourse. I will call it the Discourse of e early literacy instruction (DELI). DELI is based on certain norms, values, communicative practices etc. in relation to which teachers and children strive 'to pull off' the expected kinds of identities. Being able to perform/play a literate person in sync with DELI is a very important aspect of early literacy learning in school. Cognitive skills are of course inherent parts of this performance.

To approach DELI from the critical perspective of Axel Honneth is to emphasize how this Discourse must be rooted in a broad/open horizon of values. Honneth argues for the promotion of societal conditions leading to a situation where 'every member of a society, through a radical opening of the ethical horizon of values, is placed in a situation where his performances and abilities are recognized so that he learns to value himself' (Honneth, 2003: 151, translated by author).

A holistic and inclusive approach to early literacy teaching needs to work through the tensions between (on the one side) images of how a 'normal' child progresses through a standardized early literacy curriculum (a static and narrow horizon of values) and (on the other side) approaches aimed at recognizing the child by the opening of the horizon of values.

Referring to the indicators of the Early Literacy Story approach, one might look for ways to expand the formal curriculum with diverse literacy relevant activities such drawing (Kendrick \& McKay, 2004; Kress, 1997) and playing (Broström, 1996; Christie, 1991; Davidson, 1996; Roskos \& Christie, 2007).

Broström addresses the issue of norms and values through the notion of upbringing in his unified approach. The teacher should pursue democratic learning environments where the children actively participate (Broström, 2006a, 2006b, 2009). It is seen as problematic when childcare workers or teachers (often in friendly, welcoming ways) force children to participate in well-intended activities designed to support learning and/or development, e.g. early literacy learning. Even when the 
DANMARKS PÆDAGOGISKE UNIVERSITETSSKOLE, AARHUS UNIVERSITET

- FORSKNINGSENHEDEN BARNDOM, LÆRING OG DIDAKTIK [WWW.DPU.DK/BLD]

children carry out the activities without objections, some might not even understand the reason for the activity. In any case, the children are being socialized into (or they are adjusting to) the norms and values of a well-meant but static, teacher-managed Discourse of early literacy teaching, where the same set of activities and resources are repeated. Instead, the schoolteachers and the childcare workers 'have to cooperate with the children, support them to influence their own life, and help them to understand what they are doing and why' (Broström, 2006a: 396).

From Gee we have learned that early literacy teaching is a Discourse community (which I call DELI), built on (socially constructed) norms and values. From Broström we have learned that children should participate in the construction of these norms and values, and thus participate in the formation of the Discourse, in order to achieve a liberating, democratic education. How might we turn these insights into teaching practice regarding the expansion of the scope of what counts as relevant early literacy teaching activities, strategies and resources?

An example of how to do this is to pay attention to what resources and practices (Discourses) the children bring into their play, and discuss with the children possible ways to relate these resources and practices to the early literacy curriculum. A group of five boys in first grade spent nearly every recess one week drawing. In their drawings they created a complex sci-fi universe of striding robots and battleships, adding to a shared, ongoing narrative. The teacher and the boys agreed to bring this narrative into the early literacy teaching. After the boys had presented the drawings and sketched the universe to the classmates, everybody participated in writing up some shared spin-off stories (the teacher writing on a computer connected to a projector while the children took turns narrating). The original drawings and new ones were used as illustrations, and everything was eventually turned into a home-made sci-fi anthology, photocopied for everybody and used in activities ranging from identifying and 'hand clapping' syllables to small performances (did you know that one of the warrior robots actually planned on getting married?). The text was full of words that most of the children could not decode by applying their still limited knowledge of letter-sound relationships, but these words were embedded in a meaningful narrative that was richly resourced beyond those letters/words, which enabled the children to perform as readers, as writers and as full-blown composers, not just beyond the letters, but beyond the written story as well. This is similar to when Thomas drew on resources external to the text in his attempt to narrate an amusing story about the thief.

\section{Early Literacy Learning as Making Valuable Contributions}

According to Street, (1995), traditional approaches to early literacy teaching are inscribed in objectifying language, that is, as a specific way with words closely tied to the school and thus tied to what I call the Discourse of early literacy instruction 
DANMARKS PÆDAGOGISKE UNIVERSITETSSKOLE, AARHUS UNIVERSITET

- FORSKNINGSENHEDEN BARNDOM, LÆRING OG DIDAKTIK [WWW.DPU.DK/BLD]

(DELI). As the name suggests, objectifying language is a way of treating language/literacy as a (neutral) transcendent semiotic body (singular), imposing its autonomous, non-social qualities on its users. A distance between the child and language is constructed through the teaching practices, as Street reports in a discussion of a series of classroom observations:

Once the language is on the board, on the worksheet, in the book, and so on, it becomes a separate problem for the teacher and children to work on together ... The aim was to get children to follow her [the teacher's] own work processes and mimic them. There was little discussion of the meaning of language, of alternative interpretations of texts, or of how the teacher arrived at her sense of what they meant... In contexts such as these, it would seem, the final objective is to achieve mastery and authority over the text, whose meanings are not negotiable. (Street, 1995: 116).

Keeping in mind the point about education for democracy from the previous section, we must challenge the early literacy learning to include opportunities for the children to participate in the interpretations and meaning making. Teaching practices in childcare and school must recognize the different Discourses of the children, and strive to rethink DELI in ways that support each child in drawing on his/her Discourses in contributing to the shared early literacy events.

Broström draws on 1) Vygotsky's (1978) original findings that learning and development are cultural, social processes, 2) the constructivism of Piaget (1929) and 3) Lave \& Wenger's (1991) notion of situated learning, as he attempts to sketch a broad, Bildung-inspired approach to teaching. This is an approach that conceives of teaching as a matter of supporting the child's personal development, not merely a transfer of skills. Broström constructs a concept of teaching and learning that emphasizes the construction of meaning through the child's active participation, and at the same time points to learning/meaning-making as situated and therefore linked to contexts.

Self-worth stems from experiences of being recognized as a valued contributor to the community (Honneth, 2006). I have already touched upon this when I discussed the need to ensure an open horizon of values in relation to succeeding in terms of identity, and can now go one step further. To strive to consider each other in ways that let the individual abilities and opportunities appear as valuable for the common projects and activities might be a guiding principle for the structuring of the learning environments in line with the findings of Gee and Broström. This does not mean that every contribution has equal value. It means taking an inclusive approach to teaching that captures the important and unique aspects of the contributions from each of the children. With Gee we see the importance of linking together school, home and popular culture based Discourses with regard to equal opportunities to learn (2003). Broström (2006a) emphasizes a participatory approach to teaching across the whole field of early childhood education and care, and Honneth (2003) makes it clear that

Anders Skriver Jensen Ph.d.-stipendiat, cand.pæd. asje@dpu.dk
Institut for Didaktik

Danmarks Pædagogiske Universitetsskole

Aarhus Universitet 
DANMARKS PÆDAGOGISKE UNIVERSITETSSKOLE, AARHUS UNIVERSITET

- FORSKNINGSENHEDEN BARNDOM, LÆRING OG DIDAKTIK [WWW.DPU.DK/BLD]

the classroom as a learning environment/community (the DELI) should frame the unique and important aspects of the contributions of each child.

What these theories might point to in relation to emphasizing valued contributions in literacy teaching is the need for 1) structuring the participatory-oriented early literacy learning processes around common, flexible (linking to multiple Discourses) projects for the whole class to work with, and 2) including some forums, where the children, either individually or in small groups can present, perform or otherwise act in ways that make their contributions (to the common projects) visible, and thus objects for recognition. By participating in these common projects the children can acquire new principles/techniques for decoding or they might expand their lexical comprehension when working with new words etc., but the point is that this is done as a function of the contributions to the common projects/practices, not as an end in itself.

When the formal early literacy learning (whether this is in childcare services or in schools) is not first and foremost about acquiring some pre-reading phonemic awareness or basic reading and/or writing skills, but is primarily about participating in and contributing to common projects involving print, drawings, computer graphics etc., each child has more opportunities to make valuable contributions that add to their self-worth and their abilities with literacy.

An example is a kindergarten project called 'The City', which ran for about a month. In the beginning, the children collaborated on a frieze of the main street of the city, complete with shops and townspeople. Everything was made of cardboard, drawings, yarn, pieces of cloth, etc. As each child made up a character in the city, socalled data cards were written and drawn, connecting the characters to each other, and to the various stores and places in the city. Then the teachers and the children agreed to make a number of events unfold in the city. Among others there was a street party (the children had to write a little song and compose a dance) and an advertising campaign (the children had to work with layouts, text and symbols). And one morning, when the people of the city woke up, they realized there had been burglars in the night, stealing various items from the stores. A detective story unfolded (made up by the children, with the teacher as secretary and moderator). Along with the participative learning processes there were rich opportunities for contributing in many different ways to the unfolding literacy events. The children had many opportunities to be acknowledged by each other (and the teacher) for their contributions of creative and meaningful interpretations of printed letters and symbols, just as Thomas' peers acknowledged the contribution he made by narrating the Story About a Thief. 
DANMARKS PÆDAGOGISKE UNIVERSITETSSKOLE, AARHUS UNIVERSITET

- FORSKNINGSENHEDEN BARNDOM, LÆRING OG DIDAKTIK [WWW.DPU.DK/BLD]

\section{Closing Remarks}

In this paper I have tried to sketch an inclusive, holistic approach to early literacy teaching. It is holistic in the sense that it operates on a socio-cultural level where it is clear how identity, well-being and all-round personal development are issues that are entwined in early literacy as teaching and learning practices; practices which, of course, also include the acquisition of cognitive skills - but are never limited to this focus. It is inclusive in the sense that it transgresses the borders between special needs education and 'regular' education by claiming that the essence of early literacy teaching is not applying the so-called developmentally appropriate practices (Jensen, 2010; Razfar \& Gutiérrez, 2003), but creating project-based, literacy-rich learning environments where 1 ) every child has a fair chance of making a valuable contribution, and 2) rich cultural resources and activities are deployed according to the Discourses of the children. I have examined what DELI might look like if it were to a larger extent nurtured by the vibrant home- and peer-based Discourses of the children, and to a lesser degree tied to expectations of compliance with curriculum standards and notions of quality (Dahlberg, et al., 2007).

I address stakeholders in early childhood education in general and in early literacy in particular, as teachers, parents, children, politicians and researchers hold a shared responsibility for working towards providing the conditions under which a holistic, inclusive practice is possible. Even though Danish contemporary policy promotes a narrow image of early literacy teaching, Denmark is, along with the other Nordic countries, still largely inscribed in a pedagogical tradition that values social competencies, all-round personal development etc. over pre-set curricula (Einarsdottir \& Wagner, 2006; OECD, 2001, 2006). Together with the inclusive societal conditions (equality) provided by the traditional welfare state (Bennett \& Moss, 2010; Dahlberg \& Moss, 2005), this Nordic tradition frames the inclusive, holistic approach sketched above relatively well. But as 'free market fundamentalism rather than democratic idealism is now the driving force of economics and politics in most of the world' (Giroux \& Giroux, 2006: 22), the standardization of curricula and teaching practices, driven forward by marketization of education on a global scale, makes reconceptualization of early literacy teaching and learning practices a pressing matter for stakeholders all over the world.

\section{References}

Amrein, A. L., \& Berliner, D. C. (2003). 'The Effects of High-Stakes Testing on Student Motivation and Learning.', Educational Leadership 60: 32-38.

Beiser, F. C. (1998). 'A romantic education: The concept of Bildung in early German romanticism', in A. O. Rorty (ed) Philosophers on Education. London \& New York: Routledge. 
DANMARKS PÆDAGOGISKE UNIVERSITETSSKOLE, AARHUS UNIVERSITET

- FORSKNINGSENHEDEN BARNDOM, LÆRING OG DIDAKTIK [WWW.DPU.DK/BLD]

Bennett, J., \& Moss, P. (2010). Working for Inclusion: an overview of European Union early years services and their workforce. Edinburgh: Children in Scotland.

Bernstein, B. B. (1972). 'A Critique of the Concept of Compensatory Education', in C. B. Cazden, V. P. John \& D. Hymes (eds) Functions of Language in the Classroom, pp. 135-154. New York and London: Teachers College Press.

Broström, S. (1996). 'Frame Play with 6-Year-Old Children', European Early Childhood Education Research Journal 4(1): 89-102.

Broström, S. (2003). 'Børns læreríge leg' [Learning and children’s play], Psyke \& Logos 2: 451-469.

Broström, S. (2006a). 'Care and education: Towards a new paradigm in early childhood education', Child and youth care forum 35(5-6): 391-409.

Broström, S. (2006b) 'Education to democracy: A possible approach to early childhood education?', paper presented at the 34th Congress of the Nordic Educational Research Association (NERA), Ôrebrö, 9 - 11 march.

Broström, S. (2008) 'Transition to school: Liberation or adjustment?', paper presented at the EECERA Annual Conference, Stavanger, 3 - 6 September.

Broström, S. (2009). 'Tilpasning, frigjøring og demokrati' [Adjustment, liberation and democracy], Første Steg(2): 24-28.

Carr, M. (2005). Læringshistorier [Learning Stories]. København: Hans Reitzels Forlag.

Christie, J. F. (1991). Play and early literacy development. Albany, N.Y.: State University of New York Press.

Dahlberg, G., \& Moss, P. (2005). Ethics and politics in early childhood education. New York: RoutledgeFalmer.

Dahlberg, G., Moss, P., \& Pence, A. (2007). Beyond Quality in Early Childhood Education and Care: Languages of Evaluation (Vol. 2). New York: Routledge.

Davidson, J. I. (1996). Emergent literacy and dramatic play in early education. Albany, N.Y.: Delmar Publishers.

EASE. (2010). 'Early Years Transition Programme', URL (consulted August 2010): http://www.ease-eu.com/

Einarsdottir, J., \& Wagner, J. T. (Eds.). (2006). Nordic Childhoods and early education: philosophy, research, policy and practice in Denmark, Finland, Iceland, Norway and Sweden. Greenwich: Information Age Publishing.

Fendler, L. (2001). 'Educating flexible souls', in K. Hultqvist \& G. Dahlberg (eds) Governing the Child in the New Millenium. London: Routledge Falmer.

Fox, C. (2003). 'Playing the storyteller', in N. Hall, J. Larson \& J. Marsh (eds) Handbook of Early Childhood Literacy. London, Thousand Oaks and New Delhi: SAGE.

Gee, J. P. (2001). 'A Sociocultural Perspective on Early Literacy Development', in S. B. Neumann \& D. K. Dickinson (eds) Handbook of Early Literacy ResearchVol. 1), pp. 30-42. New York: The Guilford Press.

Gee, J. P. (2003). 'Opportunity to learn: a language-based perspective on assessment', Assessment in Education 10(1): 27-46. 
DANMARKS PæDAGOGISKE UNIVERSITETSSKOLE, AARHUS UNIVERSITET

- FORSKNINGSENHEDEN BARNDOM, LÆRING OG DIDAKTIK [WWW.DPU.DK/BLD]

Gee, J. P. (2004). Situated Language and Learning: A critique of traditional schooling. New York and London: Routledge.

Gee, J. P. (2008). Social linguistics and literacies: Ideology in Discourses (3 ed.). London: Taylor \& Francis.

Giroux, H. A. (2001). Theory and resistance in education. Westport, Conn: Bergin \& Garvey.

Giroux, H. A., \& Giroux, S. S. (2006). 'Challenging Neoliberalism's New World Order: The Promise of Critical Pedagogy', Cultural Studies $<=>$ Critical Methodologies 6(21): 21-32.

Gough, P. B., \& Tunmer, W. E. (1986). 'Decoding, Reading, and Reading Disability', Remedial and Special Education 7(1): 6-10.

Hatch, J. A. (2002). 'Accountability Shovedown: Resisting the Standards Movement in Early Childhood Education', Phi Delta Kappan 83(6): 457-462.

Holzman, L. (1997). Schools for growth: Radical alternatives to current educational models: Lawrence Erlbaum.

Honneth, A. (2003). Behovet for anerkendelse [The need for recognition]. København: Hans Reitzels Forlag.

Honneth, A. (2006). Kamp om anerkendelse [Fight for recognition]. København: Hans Reitzels Forlag.

Hoover, W. A., \& Gough, P. B. (1990). 'The simple view of reading', Reading and Writing: An Interdisciplinary Journal (2): 127-160.

Jensen, A. S. (2010) 'Early Literacy and Inclusion', paper presented at the OMEP Congress Göteborg, 11 - 13 August.

Jensen, A. S., Broström, S., \& Hansen, O. H. (2010). 'Critical perspectives on Danish early childhood education and care: between the technical and the political', Early Years 30(3): 243-254.

Jensen, A. S., Hansen, O. H., \& Broström, S. (2010). 'Sproghistorier: En bro mellem skriftsprogstilegnelse i børnehave og indskoling? [Early Literacy Stories: An Early Literacy Bridge Between Childcare and First Years of School?]' , Viden om Læsning(8).

Kendrick, M., \& McKay, R. (2004). 'Drawings as an alternative way of understanding young children's constructions of literacy'. Journal of Early Childhood Literacy, $4(1), 109-128$

Klafki, W. (2001). Dannelsesteori og didaktik - nye studier. [Educational Theory and Curriculum Studies - New Studies] Århus: Klim.

Kress, G. (1997). Before writing: Rethinking the paths to literacy. London: Routledge. Laursen, P. F., \& Hildebrandt, S. (2009). Når klokken ringer ud [As the bell rings]. København: Gyldendal.

Lave, J., \& Wenger, E. (1991). Situated learning. Cambridge: Cambridge University Press. 
DANMARKS PÆDAGOGISKE UNIVERSITETSSKOLE, AARHUS UNIVERSITET

- FORSKNINGSENHEDEN BARNDOM, LÆRING OG DIDAKTIK [WWW.DPU.DK/BLD]

Lenz Taguchi, H. (2010). Going beyond the theory/practice divide in early childhood education: introducing an intra-active pedagogy. London: Routledge.

Madsen, B. (2005). Socialpædagogik [Social Pedagogy]. København: Hans Reitzels Forlag.

Madsen, B. (2009). 'Inklusionens pædagogik: Om at vide hvad der ekskluderer, for at udvikle en pædagogik, der inkluderer [The Pedagogy of Inclusion: On knowing what excludes in order to develop a pedagogy that includes].', in C. Pedersen (ed) Inklusionens pædagogik: Fællesskab og mangfoldighed i daginstitutionen. København: Hans Reitzels Forlag.

McCollin, M., \& O'Shea, D. (2005). 'Increasing Reading Achievement of Students From Culturally and Linguistically Diverse Backgrounds', Preventing School Failure 50(1): 41-44.

Mejding, J. (1994). Den grimme ælling og svanerne? Om danske elevers læsefærdigheder [The Ugly Duckling and the Swans? On the reading skills of Danish pupils]. København: Danmarks Pædagogiske Institut.

Mellgren, E., Jensen, A. S., \& Hansen, O. H. (2010). 'Early literacy learning in the perspective of the child: Literacy Stories', in H. Müller (ed) Transition from preschool to school: Emphasizing early literacy - comments and reflections by researchers from eight European countries, pp. 21-31.

Nichols, S. L., \& Berliner, D. C. (2007). Collateral Damage: How High-Stakes Testing Corrupts America's School. Cambridge, Mass.: Harvard Education Press.

Noddings, N. (2007). When School Reform Goes Wrong. New York: Teachers College Press.

Nordenbo, S. E. (Ed.). (2009). Pædagogisk brug af test [Using Tests in Pedagogy]. Kbh.: Danmarks Pædagogiske Universitetsforlag, Dansk Clearinghouse for uddannelsesforskning.

OECD. (2001). Starting Strong: Early education and care. Paris: OECD.

OECD. (2006). Starting strong II: Early childhood education and care. Paris: OECD.

OECD. (n.d.). 'PISA', URL (consulted 07-26-2010): http://www.pisa.oecd.org/

Piaget, J. (1929). The child's conception of the world. London: Routledge \& Kegan Paul.

Rasmussen, J. (2007). 'Accountabilitypolitik [Accountability policy]', Unge Pædagoger (6): 3-21.

Razfar, A., \& Gutiérrez, K. (2003). 'Reconceptualizing Early Childhood Literacy: The Sociocultural Influence', in N. Hall, J. Larson \& J. Marsh (eds) Handbook of Early Childhood Literacy. London, Thousand Oaks, New Delhi: SAGE.

Rhedding-Jones, J. (2007). 'Kritiske perspektiver på barnehagens rammeplan (curriculum) og nasjonale styringsdokumenter [Critical Perspectives on the Curriculum of Childcare Services and National Policy Documents]', in T. Moser \& M. Röthle (eds) Ny rammeplan - ny barnehagepedagogikk? Oslo: Universitetsforlaget.

Rose, J. (2006). Independent Review of the Teaching of Early Reading: Final Report (The Rose Review). London: Department of Education and Skills. 
DANMARKS PÆDAGOGISKE UNIVERSITETSSKOLE, AARHUS UNIVERSITET

- FORSKNINGSENHEDEN BARNDOM, LÆRING OG DIDAKTIK [WWW.DPU.DK/BLD]

Roskos, K. A., \& Christie, J. F. (2007). Play and literacy in early childhood (2. ed.). New York: Lawrence Erlbaum Associates.

Snow, C. E. (2008). 'What counts as literacy in early childhood', in K. McCartney \& D. Phillips (eds) Blackwell handbook of early childhood development, pp. 274-294. Malden USA, Oxford, UK, Carlton, Australia: Wiley Blackwell.

Street, B. V. (1995). Social Literacies: Critical Approaches to Literacy in Development, Etnography and Education Real Language Series. New York: Longman.

Søndergaard, J., Arnbak, E., Brudholm, M., Elbro, C., Frost, J., Jansen, M., et al. (2005). Rapport fra Udvalget til forberedelse af en national handlingsplan for læsning[Report from the Commission on the Preparation of a National Reading Strategy]. København: Undervisningsministeriet.

The Danish Government. (2010). 'Danmark 2020: Viden > vækst > velstand > velfærd [Denmark 2020: Knowledge > growth $>$ prosperity $>$ welfare]', URL (consulted August 2010): http://www.stm.dk/publikationer/arbprog_10/index.htm Vygotsky, L. S. (1978). Mind in society. Cambridge: Harvard University Press. Westwood, P. (2009). 'Arguing the case for a simple view of literacy assessment', Australian Journal of Learning Difficulties 14(1): 3-15. 